\title{
Nest structure and occurrence of three species of Azteca (Hymenoptera, Formicidae) in Cecropia pachystachya (Urticaceae) in non-floodable and floodable pantanal areas
}

\author{
Alexsandro S. Vieira ${ }^{1}$, Odival Faccenda ${ }^{2}$, William F. Antonialli-Junior ${ }^{2} \&$ Wedson D. Fernandes $^{1}$
}

\begin{abstract}
'Programa de Pós-graduação em Entomologia e Conservação da Biodiversidade, Universidade Federal da Grande Dourados. Rodovia Dourados, Itahum, Km 12, Caixa Postal 241, 79804-970 Dourados-MS, Brazil. alexsvieira@yahoo.com.br

${ }^{2}$ Universidade Estadual de Mato Grosso do Sul. Rodovia Dourados/Itahum, KM 12, Caixa Postal 351, 79804-907 Dourados-MS, Brazil.
\end{abstract}

\begin{abstract}
Nest structure and occurrence of three species of Azteca (Hymenoptera, Formicidae) in Cecropia pachystachya (Urticaceae) in non-floodable and floodable pantanal areas. Thirty Cecropia pachystachya trees were examined in non-floodable and floodable areas to investigate the association between C. pachystachya and Azteca ants in the Pantanal of Mato Grosso do Sul, Brazil. The species Azteca ovaticeps, Azteca isthmica, and Azteca alfari were found nesting inside domatia of C. pachystachya. A. ovaticeps was the most frequent species in the trees in the floodable area, while $A$. isthmica and $A$. alfari, in the non-floodable area. A. ovaticeps and A. isthmica maintained more entrance/exit holes in comparison to A. alfari. All Azteca species maintained entrance/exit holes in the closest domatia to the apical area of the branch, due to proximity to Müllerian and pearl bodies, suggesting that these species of Azteca were influenced by their environment during evolution and became specialized. All internodal septa of each examined branch were perforated by ants, indicating the branches were inhabited by a single colony.
\end{abstract}

KEYWORDS. Ant-Plant; Azteca; Cecropia; Dolichoderinae; Mutualism; Non-floodable and floodable area.

\begin{abstract}
RESUMO. Arquitetura de ninho e ocorrência de três espécies de Azteca (Hymenoptera, Formicidae) em Cecropia pachystachya (Urticaceae) em ambiente alagável e não alagável no Pantanal. Foram analisadas 30 plantas de Cecropia pachystachya em cada ambiente alagável e não alagável no Pantanal sul-mato-grossense, Brasil, com o objetivo de investigar a associação entre formigas Azteca e C. pachystachya. Foram encontradas as espécies Azteca ovaticeps, Azteca isthmica e Azteca alfari nidificando nas domáceas da planta. A. ovaticeps foi mais frequente em plantas de área alagável, enquanto $A$. isthmica $\mathrm{e}$ A. alfari em plantas em área não alagável. A. ovaticeps e $A$. isthmica apresentaram maior quantidade de orifícios de entrada/saída em relação à $A$. alfari $\mathrm{e}$ todas as espécies mantêm próximo da região apical do ramo, orifícios de entrada/saída nas domáceas, devido à proximidade com os corpúsculos müellerianos e pérola. Isto é, essas espécies de Azteca especializaram-se ao longo da evolução influenciadas pelo ambientes. Todos os septos internodais de cada ramo analisados apresentaram-se perfurados pelas formigas, sugerindo que os mesmos são habitados por uma única colônia.
\end{abstract}

PALAVRAS-CHAVE. Ambiente não alagável e alagável; Azteca; Cecropia; Formiga-Planta; Mutualismo.

The Pantanal is one of the richest floodplains in the world in terms of species (Alho 1982). It is a habitat rich in physiognomic vegetation types as a consequence of its geomorphological and topographical characteristics, such as 'capões de mata', and gallery forests. All these formations are fragments of semi-deciduous forests (Ponce \& Cunha 1993). 'Capões de mata' are circular or elliptical-shaped earthmounds covered by vegetation (Corrêa et al. 2006) located in a sedimentary depression. During annual floods, the 'capões' become islands that are colonized by plants and animals (Oliveira-Filho 1992). The gallery forest of the Miranda River is influenced by floods during water level increase (Rodrigues \& Leitão-Filho 2004).

The alternation between long dry periods and floods is the main control mechanism of the local biodiversity, as it strongly affects the occurrence of most organisms, thus resulting in variations in species composition (Alho 1982), mainly in ants (Lange et al. 2008). Among plant species Cecropia pachystachya (Trécul) is a pioneer, evergreen, heliophyte and selective hygrophyte species, common in clearings, fallow areas ('capoeiras'), and second growth forests, widely found in Brazil in the states of Ceará, Bahia, Minas Gerais, Goiás, from Mato Grosso do Sul to Santa Catarina (Budowski 1965; Lorenzi 1992). Species of this genus are known as myrmecophytes, due to their associations with ants (Longino 1989).

In myrmecophytes, internal spaces, termed domatia (RicoGray \& Oliveira 2007), provides shelter to some ant species. In Cecropia (Loefl.), these structures consist of small hollows located in the stems or branches of trees, divided in a series of chambers separated by septa, also known as internodes (Yu \& Davidson 1997). Species of the genus Azteca (Forel) are considered associated with Cecropia, usually nesting in hollow branches or building cartoon nests inside or outside branches of the tree (Wheeler 1942). All arboreal Azteca species build "cartoon shelves" inside internodes. These structures are used by ants to store eggs, larvae, and pupae (Harada \& Benson 1988). Founding Azteca queens chew a hole through a prostoma, a dark spot located in the apical internode, into the internodal cavity. After entering, the queen closes the entrance hole with detritus, begins laying eggs, and cares for larvae and pupae. The forming colony feeds on the 
proteins stored in the queen's body until the emergence of the first workers that perforate branches and create entrance/exit holes. These workers then become responsible for caring for the colony, while the queen maintains the reproductive role (Sudd 1967; Wilson 1971).

According Harada \& Benson (1988), ants exhibit a habitat preference to nest in trees of the genus Cecropia. These authors observed that Azteca isthmica (Wheeler) becomes abundant in dryland forest habitats, while Azteca fasciata (Mann) occurs occasionally in 'capoeiras' in floodplains and floodable areas. Azteca alfari (Emery) can occur in dryland habitats as well as floodplains and floodable areas, although it prefers open areas.

These symbiotic ant-plant relationships might be products of selection, based on complex networks of direct and indirect interactions (Davidson \& Fisher 1991). Thus, natural history studies are essential to understand the basic requirements of these relationships, as well as to describe the processes that might have led to the evolutionary specializations in antplant associations (Davidson et al. 1991; Davidson \& Fisher 1991). This study was aimed at examining the relationship between ant species inhabiting $C$. pachystachya and their corresponding nest structures, focusing on the following questions: What species of ants inhabit C. pachystachya in a gallery forest and a 'capão'? Which species are the most frequent in each area? Are these Azteca ants associated with other species? Is there a pattern for the location of entrance/ exit holes in domatia in the branches of $C$. pachystachya? Are there differences in the number of entrance/exit holes in the branches in the plants of both areas? Does the number of holes depend on the size of the branch for each ant species? Is there internal communication between internodes in the branches?

\section{MATERIAL AND METHODS}

Data were collected during the months of October and November 2006, in two habitats located in the sub-regions of Miranda and Abobral in Pantanal, Corumbá - Mato Grosso do Sul State $\left(19^{\circ} 35^{\prime} \mathrm{S}, 5^{\circ} 2^{\prime} \mathrm{W}\right)$. The first area is located in a section of approximately $500 \mathrm{~m}$ of gallery forest of the Miranda River consisted of arboreal vegetation that seasonally floods. The second area consists of two 'capões', approximately 2.000 meters away from each other, covered with a non-floodable open arboreal area.

Thirty $C$. pachystachya trees were examined along a transect in each area (floodable and non-floodable area). One branch of each tree up to $4 \mathrm{~m}$ high was cut at insertion of the branch into the trunk. The following measurements were taken: distance between each entrance/exit hole in the internode until insertion of the branch into the trunk (named hole/insertion), and distance between each entrance/exit hole in the internodes until the apical region of the branch (named hole/apex). The number of entrance/exit holes in internodes, branch size, as well as presence or absence of perforation between internodal septa was examined with longitudinal cuts in the superficial area.

Ants entering and exiting the holes from domatia were captured manually and later identified using the dichotomic key of Bolton $(1994,2003)$ and by comparisons with specimens of the ant collection of the Laboratório de Mirmecologia do Centro de Pesquisas do Cacau (Ceplac/Cepec-Ilhéus, BA). Voucher specimens were deposited in the Museu de Biodiversidade da Faculdade de Ciências Biológicas e Ambientais/ FCBA of the Universidade Federal da Grande Dourados/UFGD, Dourados - Mato Grosso do Sul State. Samples of Cecropia were identified by comparison with the material deposited in the herbarium of the Universidade Federal do Mato Grosso do Sul/Campo Grande-Brazil.

\section{Statistical Analysis.}

The relationships between the hole/apex and hole/ insertion distances, as well as the average number of entrance/ exit holes in domatia of Cecropia trees of the two habitats for each Azteca species were examined with the $U$ test of MannWhitney for independent samples. The analysis of variance (non-parametric test ANOVA of Kruskal-Wallis) was used to compare the averages of hole/apex and hole/insertion distances of the three ant species. A normality test was performed and the Spearman's correlation coefficient was used to examine whether the number of entrance/exit holes was dependent on the size of the branch.

\section{RESULTS}

Occurrence of nesting species in each habitat. Two species, Azteca ovaticeps (Forel) and A. isthmica, were found in the floodable habitat, and three species, $A$. ovaticeps, $A$. isthmica, and $A$. alfari, observed in the non-floodable habitat, nesting in the internodes of $C$. pachystachya (Table I).

Colonization of branches. The most frequent species found in domatia of $C$. pachystachya in the floodable habitat was $A$. ovaticeps, while $A$. alfari occurred strictly in the non-floodable habitat (Table I). Azteca isthmica occurred in the two areas, although it was more frequently found in the non-floodable habitat (Table I). From the 60 branches of $C$. pachystachya examined, $98.3 \%$ (59 branches) were colonized by Azteca ants, and inhabited by only one species. However, in a single branch of a tree in the non-floodable habitat, Crematogaster sp. (Lund) was found in a leaf domatium and no Azteca ants inhabited this branch.

Azteca and C. pachystachya and, association with other ants. In addition to Azteca ants, other ant species were found foraging on the same branches of $C$. pachystachya, representing $18.33 \%$ of the branches examined. The ants $A$. isthmica and Crematogaster sp. 2, A. ovaticeps and Cephalotes sp. 1 (Latreille), A. ovaticeps and Pseudomyrmex sp. 1 (Lund), A. ovaticeps and Cephalotes sp. 2, were observed in the same tree in the floodable area. A. ovaticeps and Pseudomyrmex sp. 2, A. ovaticeps and Crematogaster sp. 2, A. alfari and Crematogaster sp. 2, A. ovaticeps and Cephalotes sp. 1 were observed in the non-floodable area.

Location patterns of entrance/exit holes in domatia. The entrance/exit holes of the three Azteca species were oval shaped with an average width of $1.45 \pm 0.51 \mathrm{~mm}$ and length 
Table I. Number of records of Azteca species in internodes of C. pachystachya, in two habitats of the Pantanal in Mato Grosso do Sul State.

\begin{tabular}{lcc}
\hline Nesting species & $\begin{array}{c}\text { Gallery Forest } \\
\text { (\% for habitat) }\end{array}$ & $\begin{array}{c}\text { Capão } \\
\text { (\% for habitat) }\end{array}$ \\
\hline Azteca ovaticeps & $28(77.7 \%)$ & $08(22.3 \%)$ \\
Azteca isthmica & $02(28.6 \%)$ & $05(71.4 \%)$ \\
Azteca alfari & -- & $16(100 \%)$ \\
\hline
\end{tabular}

of $2.12 \pm 0.23 \mathrm{~mm}$, slightly larger that the head of workers. The location of entrance/exit holes followed a pattern, always near the apical region of branches (Table II), regardless of the type of habitat. However, a significant variation was found between the average distances of the entrance/exit holes to the apex $\left(\chi_{(2)}^{2}=18.756 ; \mathrm{p}=0.001\right)$ and hole/insertion $\left(\chi_{(2)}^{2}=\right.$ $6.16 ; \mathrm{p}=0.047)$.

Number of entrance/exit holes in domatia. The number of entrance/exit holes varied from one to eight per branch for $A$. ovaticeps, with a mean of $\bar{x}=3.57 \pm 1.93$ in floodable area and $\bar{x}=2.63 \pm 0.74$ in the non-floodable area, both significantly different $(Z=-1.98 ; \mathrm{p}=0.046)$. For $A$. isthmica, this number varied from one to five per branch, with a mean of $\bar{x}=4.00 \pm 1.41$ in the floodable area and $\bar{x}=2.00 \pm 0.71$ in the non-floodable area, also significantly different $(\mathrm{Z}=$ -2.688; $\mathrm{p}=0.007)$. For the species $A$. alfari, which was only found in the capão, this number varied from one to three $(\bar{x}$ $=1.88 \pm 0.81$ ).

Number of holes and branch size. For $A$. ovaticeps $\left(\mathrm{r}_{\mathrm{s}(36)}\right.$ $=0.15 ; \mathrm{p}=0.378)$ as well as $A$. isthmica $\left(\mathrm{r}_{(7)}=0.52 ; \mathrm{p}=0.223\right)$ no positive correlation was found between the number of holes and branch size. However, a positive correlation was observed for the branches occupied by A. alfari $\left(\mathrm{r}_{\mathrm{s}(16)}=0.792\right.$; $\mathrm{p}=0.000)$.

Internal communication between internodes. Among all branches examined in both habitats, $94.9 \%$ presented perforated septa between internodes. Only three branches (5.1\%) of all trees in the non-floodable area lacked this type of connection. In this case, dead A. isthmica and A. ovaticeps queens were found.

\section{DISCUSSION}

This is the first report on the occurrence of A. ovaticeps in the Pantanal. Wheeler (1942) and Harada \& Benson (1988) described $A$. ovaticeps (=A. alfari var. ovaticeps) in the Amazon (Brazil), nesting in Cecropia sp. and Cecropia lyratiloba (Miquel), and in Bolivia and Costa Rica (Longino 1991). This species usually nests in other species of Cecropia, such as Cecropia distachya (Huber) and Cecropia ficifolia (Warb. \& Snethlage), and Cecropia purpurascens (Berg) in Panamá (Longino 1991).

A. alfari was expected to be found nesting in $C$. pachystachya in the Pantanal of Mato Grosso do Sul due to its broad distribution. Wheeler (1942), and Harada and Benson (1988) described this species in Belize, Costa Rica, Panama, Colombia, Venezuela and in Brazil, nesting in Cecropia adenopus (=C. pachystachya) (Mart.), Cecropia concolor
Table II. Mean $(\bar{x})$, standard deviation $( \pm \mathrm{SE})$ and U test of Mann-Whitney for the distance of the hole/apex and hole/insertion for the three Azteca ants in Cecropia pachystachya.

\begin{tabular}{lcccccc}
\hline Nesting species & Measurement & $\begin{array}{c}\mathrm{N} \\
\text { Mean } \\
(\mathrm{cm})\end{array}$ & $\begin{array}{c}\text { Standard } \\
\text { deviation }\end{array}$ & $\mathrm{Z}$ & $\mathrm{p}$ \\
\hline Azteca ovaticeps & Hole/apex & 36 & 12.47 & 12.21 & -6.803 & 0.001 \\
& Hole/ insertion & 36 & 137.03 & 68.02 & & \\
Azteca isthmica & Hole/apex & 07 & 9.62 & 5.94 & -3.130 & 0.002 \\
& Hole/ insertion & 07 & 119.52 & 53.28 & & \\
Azteca alfari & Hole/apex & 16 & 4.22 & 2.65 & -4.826 & 0.001 \\
& Hole/ insertion & 16 & 90.24 & 49.7 & & \\
\hline
\end{tabular}

(Willd.), C. distachya, C. purpurascens, Cecropia latiloba (Miquel), Cecropia ulei (Snethlage), and C. lyratiloba; in the Guianas, Cecropia angulata (Bailey); in Mexico, Belize, and Costa Rica, Cecropia obtusifolia (Bertol.) and Cecropia peltata (L.); in Guatemala, C. obtusifolia; and in Venezuela, C. peltata. Harada \& Benson (1988) also observed other genera of ants nesting in Cecropia, such as Camponotus (Mayr), Crematogaster, and Pachycondyla (Smith), but did not specify if the nesting sites were branches or leaves.

In the present study, A. ovaticeps was more frequently observed in floodable areas; $A$. isthmica in non-floodable areas as well as floodable areas; while $A$. alfari was only found in areas that never flood. Our explanation is that $A$. ovaticeps might obtain resources exclusively from the tree, while $A$. alfari and $A$. isthmica require extra resources. This would allow $A$. ovaticeps to survive in the plant even in times of isolation during floods, which would be more difficult for the other species. Barnwell (1967), studying the interaction between $A$. alfari and $C$. peltata, observed that this species forages more on trunks near the ground, indicating that this species forages on the ground. According to Adis (1981), the terrestrial fauna, formed by migrant and non-migrant groups of terrestrial and arboreal animals, need special strategies to survive in periodically flooded habitats.

The colonization of nearly one hundred percent of plants examined by Azteca species was not similar to the described by Bonato et al. (2003). These authors found that $64 \%$ of branches of $C$. purpurascens in Central Amazon were colonized by ants of four species: A. alfari, Camponotus balzani (Emery), Camponotus atriceps (Smith) $\quad(=C$. abdominalis), and Crematogaster brasiliensis (Mayr). On the other hand, the occurrence of a single species per branch is in agreement with the reported by Davidson et al. (1989), where each myrmecophytic tree provides shelter to a single ant colony and that in early stages, different founder queens may colonize different internodes of the same Cecropia branch, but a single colony usually dominates the entire tree, removing the other colonies.

The occurrence of other ant species with Azteca in Cecropia has also been reported by other authors. Each plant species, in general, is associated with many ant species and each ant species may occupy several plant species (Lapola et al. 2004). Longino (1991) observed other ant species foraging in Cecropia insignis (Liebm.), even when A. alfari was nested in the plant, for example, Camponotus, Solenopsis (Westwood), and Procryptocerus (Emery). 
The shape of entrance/exit holes of the three Azteca species is similar to the described for Azteca coeruleipennis (Emery) in $C$. peltata, characterized as simple entrance/exit holes in the central axis of the branch with 2-3 mm in diameter. Azteca xanthochroa (Roger), however, excavates a longitudinal slit for the entrance/exit holes (Longino 1991).

The location pattern of entrance/exit holes nearest the apical region of the branch for the three Azteca species have not been described in previous studies. Only Longino (1991) observed that $C$. peltata inhabited by $A$. coeruleipennis exhibited 10-20 internodes below the apex of the branch. In addition, Harada (1989) observed holes of $A$. alfari from the apical region to the median region of the branch. However, it is possible that, as the branch grows, older holes are obstructed by the bark of the tree and thus workers perforate a new hole in a more apical part of the branch. The most distant apical location of these holes might be associated with the location of Müllerian bodies, found at the base of petiole of leaves (Rickson 1976) and pearl bodies (O'dowd 1980) produced in the abaixal surface of new leaves (Harada 1989), since in Cecropia, leaves are located at the end of the branch.

The variation in the number of entrance/exit holes in a branch has also been reported in other Azteca species. Studies conducted with Azteca constructor (Emery) and A. xanthochroa demonstrated that these species maintain four to seven entrance/exit holes (Longino 1991). The larger number of entrance/exit holes of $A$. ovaticeps and A. isthmica in the floodable area might be due to physiological aspects of the tree or as a result of the influence of the flooding. Thus, the variation in the number of holes may be a relationship directly proportional to aggressiveness; more aggressive ants maintain more open holes in floodable area. This might favor a defense strategy more suitable to protect the resources offered by the trees. It may also partially explain why A. alfari maintains more entrance/exit holes as the branch grows, although this could also be associated with the size of the colony, in which few workers might require more holes to optimize the response time to defend the resources of the tree (Folgarait \& Davidson 1994).

The septa perforated between internodes per branch suggest the presence of a single colony per branch that probably access other internodes as the population increases, also favoring mobility to protect and obtain resources in the apex of the branch. According to Barnwell (1967), A. alfari usually restricts its activities to the crown of Cecropia trees. Longino (1991) observed that some branches occupied by A. alfari exhibited an internal communication of up to three holes in internodal septa.

In summary, this study reports on the occurrence of $A$. ovaticeps for the first time in the Pantanal, as well as other more frequently observed species, inhabiting the internodes of C. pachystachya in floodable area. A. alfari only occurred in the non-floodable area, suggesting that this species of Azteca might have become specialized in certain environments during evolution. The nest structure might have been influenced by floodable habitats, for instance, the few entrance/exit holes of A. ovaticeps and A. isthmica in the floodable area compared with non-floodable area. Except the location pattern of entrance/exit holes nearest the apical region of the branch for the three Azteca species that would be result of the production of Müllerian and pearl bodies, independently of non-floodable area. Regarding aggressiveness, further studies could reveal if ants Azteca of floodable areas are more aggressive compared with those of non-floodable areas.

Acknowledgments. We thank Dr. Jacques Hubert Charles Delabie from the Myrmecology Laboratory of the Research Center of Cacao (CEPLAC/ CEPEC-Ilhéus, BA), for specimen identification; to CAPES (Coordenação de Aperfeiçoamento de Pessoal de Nível Superior) for the Masters degree fellowship granted to the first author and WFAJ acknowledge their research grants by $\mathrm{CNPq}$ (Conselho Nacional de Desenvolvimento Científico e Tecnológico, process number 23/200085/2007).

\section{REFERENCES}

Adis, J. 1981. Comparative ecological studies of the arthropod fauna in Central Amazonian inundation forest. Amazoniana 7: 87-173.

Alho, C. J. R. 1982. Brazilian Rodents: Their Habitats and Habits. p. 143-166. In: Mares, M. A. \& H. H. Genoways (eds.). Mamalian Biology in South America. Special Publication Series, vol. 6, Pittsburgh, University of Pittsburgh, xii +539 p.

Barnwell, F. H. 1967. Daily patterns in the activity of the arboreal ant Azteca alfari. Ecology 48: 991-993.

Bolton, B. 1994. Identification guide to the ant genera of the world. Cambridge, Harvard University Press, 222 p.

Bolton, B. 2003. Synopsis and classification of Formicidae. Gainesville, The American Entomological Institute, 370 p.

Bonato, V.; R. Cogni \& E. M. Venticinque. 2003. Ants Nesting on Cecropia purpurascens (Cecropiaceae) in Central Amazonia: Influence of Tree Height, Domatia Volume and Food Bodies. Sociobiology 42: 719-726.

Budowski, A. 1965. Distribution of tropical American rain forest species in the light of successional progresses. Turrialba, Turrialba 15: 40-42.

Corrêa, M. M.; W. D. Fernandes \& I. R. Leal. 2006. Diversidade de formigas epigéicas (Hymenoptera: Formicidae) em capões do Pantanal Sul Matogrossense: relações entre riqueza de espécies e complexidade estrutural da área. Neotropical Entomology 35: 724-730.

Davidson, D. W. \& B. L. Fisher. 1991. Symbiosis of ants with Cecropia as a function of light regime, p.198-212. In: Cutler, D. F. \& C. R. Huxley, Editors. Ant-Plant Interactions. Oxford, Oxford University Press, 601 p.

Davidson, D. W.; R. R. Snelling \& J. T. Longino. 1989. Competion among ants for myrmecophytes and the significance of plant trichornes. Biotropica 21: 64-73.

Davidson, D. W.; R. B. Foster; R. R. Snelling \& P. W. Lozada. 1991. Variable composition of some tropical ant-plant symbioses, p.145-162. In: Price, P. W.; T. M. Lewinsohn; G. W. Fernandes \& W. W. Benson. (Editors). Plant-Animal Interactions: Evolutionary Ecology in Tropical and Temperate Regions. New York, John Wiley \& Sons, xiv+ 693 p.

Folgarait, P. J. \& D. W. Davidson. 1994. Antiherbivore defenses of myrmecophytic Cecropia under different light regimes. Oikos 71: 305-320.

Harada, A. Y. 1989. Estrutura de colônias de Azteca alfari Emery (Hymenoptera, Formicidae, Dolichoderinae) em plantas de Cecropia concolor (Moraceae). Revista Brasileira de Entomologia 33: 169-182.

Harada, A. Y. \& W. W. Benson. 1988. Espécies de Azteca (Hymenoptera, Formicidae) especializadas em Cecropia spp. (Moraceae): Distribuição Geográfica e Considerações ecológicas. Revista Brasileira de Entomologia 32: 423-435.

Lange, D.; W. D. Fernandes; J. Raizer \& R. Silvestre. 2008. Activity of Hypogeic Ants (Hymenoptera: Formicidae) in floodable and Nonfloodable Forest Patches in the Brazilian Pantanal. Sociobiology 51: 661-672.

Lapola, D. M.; E. M. Bruna \& H. L. Vasconcelos. 2004. Amizade tênue: mutualismo entre plantas e formigas na Amazônia. Ciência Hoje 34: $28-33$.

Longino, J. T. 1989. Geographic variation and community structure in na ant-plant mutualism: Azteca and Cecropia in Costa Rica. Biotropica 21: $126-132$. 
Longino. J. T. 1991. Azteca ants in Cecropia trees: taxonomy. colony structure, and behaviour, p.198-212. In: Cutler, D. F. \& C. R. Huxley, Editors. Ant-Plant Interactions. Oxford, Oxford University Press, $601 \mathrm{p}$.

Lorenzi, H. 1992. Árvores brasileiras: manual de identificação e cultivo da plantas arbóreas nativas do Brasil. V. 01. Nova Odessa, Editora Plantarum, $382 \mathrm{p}$.

O’Dowd, D. J. 1980. Pearl bodies of a Neotropical tree, Ochroma pyramidale: Ecological implications. American Journal of Botany 67: 543-549.

Oliveira-Filho, A. T. 1992. Floodplain 'murundus' of Central Brazil: Evidence for the termite-origin hypothesis. Journal of Tropical Ecology 8: 1-19.

Ponce, V. M. \& C. N. Cunha. 1993. Vegetated Earthmounds in Tropical Savannas of Central Brazil: A Synthesis: With Special Reference to the Pantanal do Mato Grosso. Journal of Biogeography 20: 219-225.

Rickson, F. R. 1976. Anatomic Development of the leaf trichilium and Müllerian bodies of Cecropia peltata L. American Journal of Botany 63: $1266-1271$.
Rico-Gray, V. \& P. S. Oliveira. 2007. The Ecology and Evolution of antplant interactions. Ed. The University of Chicago press, $331 \mathrm{p}$.

Rodrigues, R. R. \& H. F. Leitão-Filho. 2004. Matas ciliares: conservação e recuperação. 2. ed. São Paulo, Editora da Universidade de São Paulo, Fapesp, 320 p.

Sudd, J. H. 1967. An introduction to the behavior of ants. London, Edward Arnold Ltd., 200 p.

Wheeler, W. M. 1942. Studies of netropical ant-plants and their ants. Bull. Mus. Comp. Zool., Harvard 90: 1-262.

Wilson, E. O. 1971. The insect societies. Cambridge, Belnap Press of Havard University Press, 548 p.

Yu, D. W. \& D. W. Davidson. 1997. Experimental studies of speciesspecificity in Cecropia-ant relationships. Ecological Monographs 67: 273-294. 